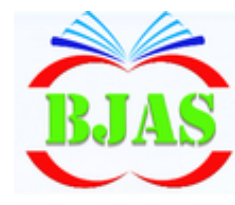

ISSN $1814-5868$
Available online at http://bjas.bajas.edu.iq https://doi.org/10.37077/25200860.2021.34.1.11 College of Agriculture, University of Basrah

Basrah J. Agric. Sci., 34(1): 124-138, 2021

\section{Basrah Journal of Agricultural Sciences}

E-ISSN: 2520-0860

\title{
Responses of Local Wheat Varieties to Greenbug Schizaphus graminum and Bird-Cherry Oat Aphid Rhopalosiphum padi Infestation
}

\author{
Haider D. Al-Hussine ${ }^{1 *}$ \& Aqeel A. Alyousuf ${ }^{2}$ \\ ${ }^{1}$ Basrah Department of Plant Protection, Ministry of Agriculture, Basrah, Iraq. \\ ${ }^{2}$ Department of Plant Protection, College of Agriculture, University of Basrah, Basrah, Iraq. \\ aqeel.alyousuf@okstate.edu \\ *Correspondence author Email: haider.dhaerb@gmail.com
}

Received $2^{\text {nd }}$ July 2020; Accepted 22 September 2020; Available online 19 February 2021

\begin{abstract}
Field and laboratory studies were conducted to assess the sensitivity of 12 varieties of local wheat varieties (IPA-95, IPA-99, Abu-Ghreib, Babel-113, Bhooth-10, Bhooth-22, and Bhooth-158, Baraka, Tammuz, Fatih, Latifia and Rasheed) against infestation by Greenbug Shizaphis graminum and Bird-Cherry Oat Aphid Rhopalosihum padi in the province of Basrah. The field trial was carried out in Al-Nashwa district, county of Shatt Al-Arab, during the growing season 2019/2020. The first infestation of $R$. padi appeared on 9/1/2020, and reached the peak of population density on 30/1/2020, while the first appearance of $S$. graminum was on $17 / 1 / 2020$; it reached its peak on 13/2/2020. The results of responses of local wheat varieties to the infestation of Greenbug showed that the highest average population density of greenbug was on Bhooth-158, Abu-Ghraib, Bhooth-22, and Babel-113 reaching 51.59, 17.84, 16.41, and 16.63 aphids/plant, respectively. Whereas the lowest population densities were at Fatih, Tammuz, Bhooth-10, Rasheed, and IPA-99, with averages of 8.28, 8.09, 8.87, 7.19, and 7.62 aphids.plant ${ }^{-1}$, respectively. The highest density rate of $R$. padi was recorded on the cultivars


while the verities Bhooth-22, Bhooth-158, and IPA-99 recorded the lowest population density rate $\left(89.03,99.41\right.$, and 100.25 aphids.plant $\left.{ }^{-1}\right)$ compared to the other varieties. The results of the chemical analysis determined the proportions of some metabolites of the local wheat varieties and their relationship to the infestation of Greenbug and showed that phenols have an effective role by reducing the population density of aphids. The verities Rasheed and IPA-99 which recorded low population rates of the aphids have the highest rates of phenols at a rate of 7 and $6.78 \mathrm{mg} .100 \mathrm{~g}^{-1}$ dry weight Also, varieties Abu-Ghraib, IPA-99, and Rasheed cultivars recorded the highest productivity rates (weight of thousand grains), with an average of $33.47,43$, and $67.42 \mathrm{~g}$, respectively.
\end{abstract}

Keywords: Resistant variety, Wheat, Schizaphus graminum, Rhopalosiphum pad.

\section{Introduction}

Winter wheat was grown in over 6331000 thousand Dunums in Iraq during the growing season of 2019/2020 (CSO, 2020). Wheat crop is infested with various economically important insect pests; aphids (Hyalopterus prune Fabr, Metopolophium sacchari Zehner, , Rhopalosihum maidis Fitch, $R$. padi L., Sitobion avena Fabricius, and Schizaphus 
graminum Rondani) are the most important annual insects' pests in Iraq (Ali, 2012). Greenbug or wheat aphids $S$. graminum infestations are more consistent in the wheat fields especially during early fall growth (AlMousawi et al., 1983), which causes severe direct and indirect damage to the wheat crop. Aphids inject salivary secretions containing pectinesterase and polygalacturonase into plant tissues (Ma et al., 1990). These enzymes are toxic to the host plant and have a great role in destroying the pectin layer (Dreyer \& Campbell, 1984), leading to damaging to the chloroplasts, reducing the rates of photosynthesis, and then the death of plants (Al-Mousawi et al., 1983). Because aphids are such a consistent pest of winter wheat in many fields, excessive sprays of pesticides are applied to control the pest, which increases the production costs, environmental pollution (Riah et al., 2014). Scientific efforts have been focused on plant resistance as an alternative management approach, which is considered an effective ecological-friendly technique $(\mathrm{Gu}$, 2008). Resistant wheat varieties have been used in different IPM programs against aphids (Aslam et al, 2004; Yahya et al., 2017). The resistant mechanism tools are varied among the varieties; some varieties prevent pests from feeding or laying eggs. Meanwhile, varieties could be resistant due to the lack of some desirable or important nutrients for the insect's life (Gillott, 2005), or they showed antibiosis behavior which enables the plant to secrete toxic secondary plant metabolites which may affect the biological performance of the insect (Kogan \& Ortman, 1978; Horber, 1980). Moreover, resistant plants showed the ability of tolerance against the pest infestation that can survive below the levels of resistance (Mitchell et al., 2016).

In Iraq, Hussein \& Al-Nuaimi (2013) tested the resistance of local wheat varieties:
Tammuz2, Iraq, IPA-99, Rasheed, and AbuGhraib. They found that both Iraq and Tammuz were less attractive (resistant) to Greenbug S. graminum. Some local varieties are distinguished by the relatively high productivity of wheat crop in Iraq. Al-Halfie (2015) indicated that Abu-Ghraib variety produced the highest yields compared to Latifah \& Tammuz. Al-Aseel et al. (2018) mentioned that IPA-99 variety produced high yield compared to other tested varieties. Despite the high production of some local varieties, they faced many difficulties especially decreasing the yield due to pest infestations such as Sauna insects and aphids (Ali, 2012; Shblawy \& Al-Jorany, 2018). Therefore, it is necessary to screen the resistant varieties of Iraqi local wheat plants against infestation with economic important pests, especially Greenbug in the province of Basrah.

The objective of this study is to design a protocol that is reliable and repeatable to quantitatively describe the phenotypic response of existing local wheat varieties to Greenbug S. graminum and Bird-Cherry Oat Aphid Rhopalosiphum padi feeding.

\section{Materials \& Methods}

\section{Varieties of wheat used in the study}

Grains of some local wheat varieties (AbuGhraib, IPA-95, IPA-99, Babell-133, Baraka, Bhooth-10, Bhooth-22, Bhooth-158, Tammuz, Rashid, Fatih, and Latifia) were obtained from several reliable sources such as the General Organization for Seed Certification, the Technological Centre for Seed Development and the Seed Research Center in Province of Baghdad, Iraq. These varieties are used in the cultivation of wheat fields in most of the provinces of Iraq. 
Field bioassay of existing local wheat varieties to $S$. graminum and $R$. padi infestation

The field trial was carried out at a private field in Al-Nashwa region, county of Shatt Al-Arab, during the growing season 2019/2020, to evaluate grain local wheat varieties for resistance and yield response to Greenbug (GB) under field conditions. The field (1000 $\mathrm{m}^{2}$ ) was divided into four blocks; each block was divided into twelve experimental units, which were $12 \mathrm{~m}^{2}(3 \times 4 \mathrm{~m})$, with $1 \mathrm{~m}$. alleys, arranged in a randomized complete block design with 4 replications. Plots were planted on 15/11/ 2019. The varieties were distributed randomly on the experimental units and were planted in 20 lines per experimental unit, and the distance between every two lines was 15 $\mathrm{cm}$. All agricultural operations were applied such as weed control and chemical fertilization. The first appearance of $R$. padi has started on 9/1/2020 and Greenbug $S$. graminum found on 17/1/ 2020. Aphids were counted weekly after aphids had been established in all plots.

A random sampling protocol was followed to determine the population of each species per plant (5 plants) in each experimental unit. Aphid's species were identified at the Museum of Natural History, University of Baghdad.

At the end of the season, plots were harvested on 22 /5/ 2020. The yield was calculated by calculating and weighing 1000 grains. Data were analyzed using ANOVA and $\operatorname{LSD}(P=0.05)$.

\section{Quantification of biochemicals in wheat varieties}

Samples of plant leaves were collected randomly from each wheat variety (10 leaves of 5 plants from each experimental unit, separately). The leaves were washed and dried in an electric oven at $70^{\circ} \mathrm{C}$, then ground and subjected to the following biochemical analysis:

Determination of chlorophyll: Chlorophyll $a, b$, and the total chlorophyll (chlorophyll a and $b$ ) of each wheat variety were determined according to the method of Harborn (1984). Sample tissue $(1 \mathrm{gm})$ was added to $5 \mathrm{ml}$ of acetone $80 \%$ for. After the filtration, the filtrate was transferred to a volumetric flask of 100 ml which filtered with $20 \mathrm{ml}$ of acetone $80 \%$ (Goodwin, 1976). Absorption was measured at the two wavelengths 663 and $645 \mathrm{~nm}$ by using a spectrophotometer (Type-UV-9200 UK). The concentration of chlorophyll (mg /100 g of fresh leaves) was calculated by using the following equation:

Chlorophyll $A$

$$
\begin{aligned}
& =12.7 \times D 663 \\
& -2.69 \times D 645
\end{aligned}
$$

Chlorophyll $B$

$$
\begin{aligned}
& =22.9 \times D 645 \\
& -4.68 \times D 663
\end{aligned}
$$

Total Chlorohyll

$$
\begin{aligned}
& =20.2(D 645 \\
& +8.02 \times D 663) \\
& \times\left(\frac{V}{W} \times 100\right) 100
\end{aligned}
$$

D645 = absorption value at $645 \mathrm{~nm}$ wavelength D663 $=$ absorption value at $663 \mathrm{~nm}$ wavelength $\mathrm{V}=$ final volume of filtrate $(20 \mathrm{~mL})$

$\mathrm{W}=$ leaves weight (1) $\mathrm{g}$

\section{Quantification of total phenolic:}

$2.5 \mathrm{~g}$ of the dry leaves for each variety separately was taken, and extraction was carried out with $200 \mathrm{ml}$ of distilled water. It was boiled for an hour in a water bath and was kept soaked for the next day. After the filtration, $1 \mathrm{ml}$ of the filtrate was mixed with 
$1.5 \mathrm{ml}$ of reagent folin $(10 \%)$ and left for 5 minutes. The mixture was mixed with $1.5 \mathrm{ml}$ of anhydrous sodium carbonate solution $\mathrm{NaCo} 3(6 \%)$ and left for 40 minutes at room temperature (Waterhouse, 2002). The absorbance was taken at a wavelength of 725 by using the spectrophotometer. The blank was $1 \mathrm{ml}$ of distilled water $+1.5 \mathrm{ml}$ Follen reagent $+1.5 \mathrm{NaCo} 3$

\section{Determination of protein}

Protein determination was conducted according to the Kjeldahl method described by Cresser and Parsons (1979); 0.2 gm of dried leaves was hydrolyzed with $5 \mathrm{ml}$ concentrated sulfuric acid containing two copper catalyst tablets in a heat block at $400{ }^{\circ} \mathrm{C}$ for $2 \mathrm{~h}$. Then, $3 \mathrm{ml}$ of a mixture (4\% perchloric acid $+96 \%$ concentrated sulfuric acid) was added to the hydrolysates, and heated until the solution is clear. Finally, distilled water $(50 \mathrm{ml})$ was added to the solution after cooling. The total nitrogen was estimated according to Page's (1982) method.

$$
\begin{aligned}
\% \text { Nitrogen }= & \text { acid volume } H C L \times 0.02 \\
& \times 14 \times 50 \times 100 \\
& \div 1000 \times 0.2 \times 10 \\
\% \text { Protein }= & \% \text { Nitrogen } \times 6.25
\end{aligned}
$$

\section{Effect of biochemicals on the population} density of $S$. graminum and $R$. padi

After that, a correlation of biochemicals of the local wheat varieties with a population density of $S$. graminum and $R$. padi were done to determine the resistance of the varieties against the infestation of these aphids.
The productivity of local wheat varieties in the field

After harvesting the local wheat varieties manually, the productivity of each variety was calculated separately by calculating a thousand grains for each variety, and then weighing them in a sensitive balance and placed in bags, and the data were recorded.

\section{Statistical analysis}

Results were statistically analyzed by using An ANOVA analysis. The averages were compared using the lowest LSD significant difference at a probability level of 0.05

\section{Results \& Discussion}

Responses of local wheat varieties to Greenbug $S$. graminum and $R$. padi infestation

The results of the population density of Greenbug on the local wheat varieties showed significant differences among the densities of the aphid on the wheat varieties. The highest density was recorded on the varieties Bhooth158, Abu-Ghraib, Bhooth-22, and Babel-113 reaching 51.59, 17.84, 16.41, and 16.63 aphids.plant ${ }^{-1}$ respectively, while the lowest population density were 8.28, 8.09, 8.87, 7.19, and 7.62 aphids/plant on Fatih, Tammuz, Bhooth-10, Rasheed and IPA-99, respectively (Figure 1). The results also showed that the first infestation of $S$. graminum appeared on the wheat field on 17/1/2020; the average population density of the insect was 0.51 aphids.plant $^{-1}$, and the peak of population density reached 53.32 aphids.plant ${ }^{-1}$ in the eighth week after the first infestation on 13/2/2020. The population disappeared after the ninth week of the infestation of Greenbug (Fig. 2). 




Fig. (1): The population density of $S$. graminum on the local wheat varieties.

Fig. (2): Weekly population density of $S$. graminum on the wheat yield during the growing season 2019/2020.

The results of responses of Bhooth-158, Abu-Ghraib, Bhooth-22, and Babel-113 to Greenbug during the growing season (Table 1) showed that the lowest population densities of the pest were recorded at the $1^{\text {st }}$, with averages of $1,0.25,0$, and 0 aphids.plant ${ }^{-1}$ respectively. The population's peak of the aphids was reported in the $7^{\text {th }}$ week, with averages of $92.75,73.50,60.25$, and 61.75 aphids.plant ${ }^{-1}$ respectively. Similarly, Fatih, Tammuz, Bhooth-10, IPA-99, and Rasheed recorded the population of Greenbug $(0,75,3$, and 0.0 aphids.plant ${ }^{-1}$ respectively) in the $1^{\text {st }}$ week, and the density increased gradually reaching the highest population $(38,40.25,53.75,50.25$, and 18.50 aphids.plant $\left.{ }^{-1}\right)$ respectively in the $7^{\text {th }}$ week. 
Al-Hussine \& Alyousuf / Basrah J. Agric. Sci., 34(1): 124-138, 2021

Table (1): The average weekly population density of $S$. graminum on the local wheat varieties during the growing season of $2019 / 2020$.

\begin{tabular}{l|ccccccc}
\hline \multirow{2}{*}{ Varieties } & \multicolumn{7}{c}{ Population density of $S$. graminum (mean \pm SE) after (week) of the infestation } \\
\cline { 2 - 8 } & $\mathbf{1}^{\text {st }}$ & $\mathbf{2}^{\text {nd }}$ & $\mathbf{3}^{\text {rd }}$ & $\mathbf{4}^{\text {th }}$ & $\mathbf{5}^{\text {th }}$ & $\mathbf{6}^{\text {th }}$ & $7^{\text {th }}$ \\
\hline Abu-Ghraib & $0.25 \pm 0.25$ & $0.00 \pm 0.00$ & $0.75 \pm 1.25$ & $10.75 \pm 9.46$ & $14.00 \pm 0.91$ & $44.50 \pm 2.32$ & $73.50 \pm 1.19$ \\
Babil-113 & $0.00 \pm 0.00$ & $0.00 \pm 0.00$ & $0.50 \pm 0.50$ & $9.75 \pm 0.85$ & $2.75 \pm 0.47$ & $34.25 \pm 2.01$ & $61.75 \pm 3.96$ \\
Barka & $0.50 \pm 0.50$ & $0.25 \pm 0.25$ & $1.25 \pm 0.75$ & $6.00 \pm 5.35$ & $28.25 \pm 1.22$ & $48.25 \pm 9.10$ & $43.25 \pm 2.59$ \\
Bhooth-10 & $3.00 \pm 3.00$ & $0.25 \pm 0.25$ & $0.25 \pm 0.25$ & $3.50 \pm 2.06$ & $2.75 \pm 0.47$ & $7.50 \pm 0.64$ & $53.75 \pm 3.35$ \\
Bhooth-158 & $1.00 \pm 1.00$ & $0.00 \pm 0.00$ & $5.50 \pm 5.17$ & $5.25 \pm 5.25$ & $1.75 \pm 0.47$ & $66.50 \pm 1.19$ & $92.75 \pm 1.49$ \\
Bhooth-22 & $0.00 \pm 0.00$ & $1.00 \pm 0.85$ & $1.75 \pm 0.85$ & $17.25 \pm 2.49$ & $23.50 \pm 1.93$ & $27.50 \pm 1.04$ & $60.25 \pm 1.10$ \\
Fatih & $0.00 \pm 0.00$ & $0.25 \pm 0.25$ & $3.75 \pm 2.05$ & $5.00 \pm 0.91$ & $9.75 \pm 0.85$ & $11.50 \pm 0.64$ & $38.00 \pm 0.40$ \\
IPA-95 & $0.67 \pm 0.57$ & $0.00 \pm 0.00$ & $4.33 \pm 3.32$ & $9.00 \pm 0.50$ & $9.33 \pm 0.76$ & $22.33 \pm 1.25$ & $66.33 \pm 1.52$ \\
IPA-99 & $0.00 \pm 0.00$ & $0.00 \pm 0.00$ & $0.50 \pm 0.28$ & $1.25 \pm 1.25$ & $2.25 \pm 0.25$ & $6.75 \pm 0.75$ & $50.25 \pm 3.42$ \\
Latefia & $0.00 \pm 0.00$ & $0.50 \pm 0.50$ & $0.25 \pm 0.25$ & $8.50 \pm 0.64$ & $12.50 \pm 0.64$ & $16.25 \pm 1.25$ & $32.25 \pm 2.39$ \\
Rasheed & $0.00 \pm 0.00$ & $0.00 \pm 0.00$ & $7.50 \pm 5.85$ & $15.50 \pm 12.67$ & $6.50 \pm 1.32$ & $9.50 \pm 1.25$ & $18.50 \pm 0.64$ \\
Tammuz & $0.75 \pm 0.75$ & $0.75 \pm 0.75$ & $0.25 \pm 0.25$ & $8.75 \pm 8.75$ & $22.25 \pm 5.39$ & $4.24 \pm 10.22$ & $40.25 \pm 1.25$ \\
\hline
\end{tabular}

LSD value $(0.05)=7.24$ 
The results of the responses of the local wheat varieties to the infestation of BirdCherry Oat Aphid under the field condition (Fig. 3) showed that the highest aphid's population density was recorded on IPA-95, Rasheed and Abu-Ghraib, with an average of 139.83,135 and 169.31 aphids.plant ${ }^{-1}$, while the variety Bhooth-22, Bhooth-158, and IPA99 (89.03, 99.41 and 100.25 aphids.plant ${ }^{-1}$ respectively) have the lowest density compared to other varieties. The first infestation of $R$. padi appeared on 9/1/2020, with an average of 115.52 aphids.plant ${ }^{-1}$. The population reached a peak on 30/1/2020; with an average of 200 aphids.plant $^{-1}$, then the density gradually decreased to 4.80 aphids.plant ${ }^{-1}$ in the $8^{\text {th }}$ week (Fig. 4).

According to the results of responses of the local wheat varieties against Bird-Cherry Oat Aphid during the growing season (Table 2), Abu-Ghraib and IPA- 95 recoded 130 and 143 aphids.Plant ${ }^{-1}$, respectively in the $1^{\text {st }}$ week. Then, the population density rate of the pest reached the highest population (317.25 and 278.33 aphids.Plant ${ }^{-1}$, respectively) in the $4^{\text {th }}$ week. Similarly, the varieties IPA-99, Bhooth22, and Bhooth-158 recorded 108, 75, 47 and 119.75 aphids.Plant ${ }^{-1}$, respectively, in the $1^{\text {st }}$ week; then, the population reached the highest density of 169, 170.70, and 171.75, aphids.Plant ${ }^{-1}$ respectively in the $3^{\text {rd }}$ and $5^{\text {th }}$ week. The lowest density was recorded in the $8^{\text {th }}$ week.

Depending on the above results, the responses of local wheat varieties varied against Greenbug. The varieties Fatih, Tammuz, and Bhooth-10, IPA-99, and Rasheed were comparatively resistant with a minimum density of Greenbug; while the varieties Bhooth-158, Abu-Ghraib, Bhooth-22, and Babel-113 were found as susceptible with a maximum population of Greenbug. The present results can be compared with several studies, which confirmed that the resistant lines/varieties had the least population density of Greenbug. Aslam et al. (2004) reported that the resistant variety Inqlap-91 had the lowest number of aphids compared to the susceptible variety Pnd-1 that had the highest density. Zeb et al. (2011) tested the resistance of different varieties (Pirsabak-2004, pirsabak-2005, pirsabak-2008, KT2004, Khyber-81, PR1, R2, NRL0320, and Saleem-2000), they found that the susceptible variety PR1 recorded the highest average density for aphids, including $S$. graminum, with an average of 42.20 aphids.plant ${ }^{-1}$, compared to the sensitive variety Pirsabak-2004, which recorded the lowest population density of aphids. Also, Bakry \& Shakal (2020) stated that Giza-171 (susceptible variety) had the highest density of Greenbug, compared to variety Line 4 had the lowest density.

Regarding the response of the local wheat varieties to Bird-Cherry Oat aphid's infestation. The results of this study have revealed that the varieties Abu-Ghraib and the cultivar IPA-95 were susceptible to the infestation (highest population density) of $R$. padi compared to the IPA-99, and Bhooth-158 which showed resistant with the lowest density rates of the aphid.

Many studies revealed that the variation of resistance of wheat varieties against $R$. padi; one of them was the stud of Yahya et al. (2017) who stated that the highest population density of aphids recorded on variety NM-1-8183-8 and NM-3-3341-7 (susceptible line); while the lowest population of aphids was reported on variety Faisal Apad-08 (resistant line). 


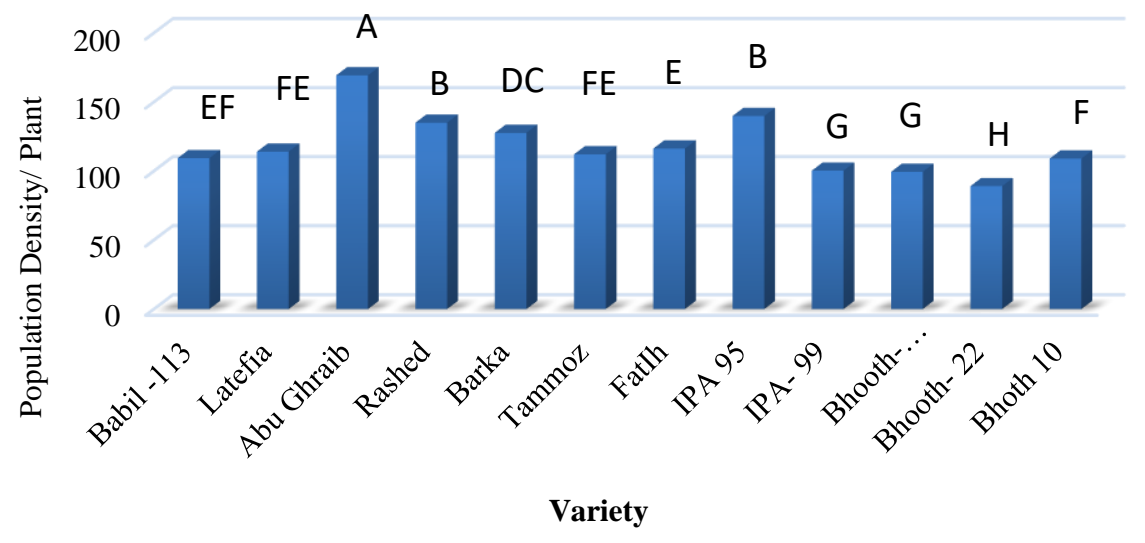

Fig. (3): The population density of $R$. padi on local wheat varieties.

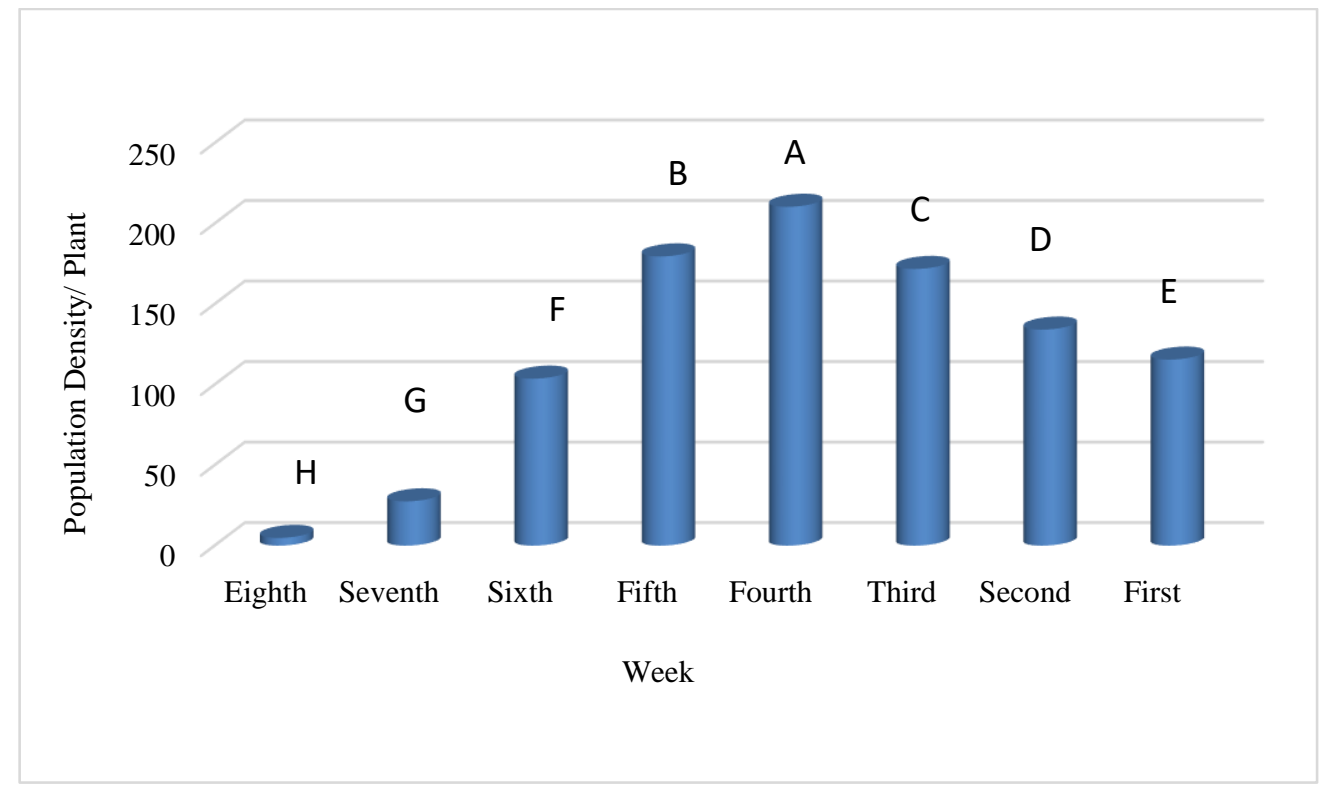

Fig. (4): Weekly population density of $R$. padi on local wheat varieties, during the growing season of 2019/2020.

Also, Papp \& Mesterházy (1993) indicated that the variety GK Zombor was the most resistant variety compared to the sensitive variety GX Lili, which recorded the highest infestation rate of aphids compared to the tested wheat varieties. Although the higher population density of Bird-Cherry Oat Aphid on wheat in the field, Greenbug was the most harmful to the infested wheat plants; it caused more damage to the infested wheat plants that result from toxic secretions during the feeding process. The toxic effects of the Greenbug's saliva lead to the brown spots on the leaves, and usually the high population infestation severely damage plants (Fig. 5). Ma et al. (1990) stated that these secretions contain enzymes that are excreted with saliva during the feeding that destroy the pectin layer, the main component in the middle plate and primary wall cells in the plant (Dreyer \& Campbell, 1984). 
Table (2) the average weekly population density of $R$. padi on local wheat varieties during the growing season of $2019 / 2020$.

\begin{tabular}{|c|c|c|c|c|c|c|c|c|}
\hline \multirow{2}{*}{ Varieties } & \multicolumn{8}{|c|}{ Population density of $R \cdot$ padi $($ mean \pm SE) after (week) of the infestation } \\
\hline & $\mathbf{1}^{\text {st }}$ & $2^{\text {nd }}$ & $3^{\text {rd }}$ & $4^{\text {th }}$ & $5^{\text {th }}$ & $6^{\text {th }}$ & $7^{\text {th }}$ & $8^{\text {th }}$ \\
\hline Abu-Ghreib & $130.00 \pm 8.43$ & $167.50 \pm 7.68$ & $203.25 \pm 11.03$ & $317.25 \pm 10.32$ & $326.25 \pm 8.00$ & $168.75 \pm 5.77$ & $36.25 \pm 2.92$ & $5.25 \pm 1.31$ \\
\hline Babil-113 & $107.75 \pm 2.01$ & $130.25 \pm 4.30$ & $148.75 \pm 7.60$ & $222.25 \pm 10.4$ & $158.25 \pm 10.80$ & $73.75 \pm 2.49$ & $33.75 \pm 2.28$ & $0.00 \pm 0.00$ \\
\hline Barka & $98.00 \pm 3.34$ & $101.00 \pm 2.73$ & $143.50 \pm 4.73$ & $271.75 \pm 7.46$ & $236.00 \pm 17.78$ & $129.25 \pm 6.90$ & $33.00 \pm 2.41$ & $8.50 \pm 0.64$ \\
\hline Bhooth- 10 & $137.25 \pm 19.58$ & $136.50 \pm 3.42$ & $142.00 \pm 2.94$ & $165.50 \pm 7.02$ & $158.25 \pm 14.84$ & $102.00 \pm 2.58$ & $28.25 \pm 2.98$ & $2.50 \pm 0.28$ \\
\hline Bhooth- 158 & $119.75 \pm 13.98$ & $161.00 \pm 10.40$ & $171.75 \pm 8.25$ & $136.00 \pm 5.04$ & $103.25 \pm 2.95$ & $90.75 \pm 2.78$ & $12.75 \pm 0.85$ & $0.00 \pm 0.00$ \\
\hline Bhooth -22 & $47.00 \pm 6.52$ & $75.50 \pm 2.53$ & $81.50 \pm 1.70$ & $157.75 \pm 5.61$ & $170.75 \pm 2.49$ & $140.25 \pm 7.05$ & $33.00 \pm 1.08$ & $6.50 \pm 0.64$ \\
\hline Fatih & $115.75 \pm 9.56$ & $156.00 \pm 3.24$ & $165.25 \pm 5.58$ & $166.25 \pm 13.04$ & $142.25 \pm 6.78$ & $153.00 \pm 4.60$ & $24.75 \pm 1.43$ & $7.25 \pm 0.47$ \\
\hline IPA- 99 & $108.75 \pm 12.57$ & $124.00 \pm 7.16$ & $169.00 \pm 4.74$ & $163.50 \pm 2.21$ & $134.75 \pm 6.77$ & $64.75 \pm 3.81$ & $27.75 \pm 2.05$ & $9.50 \pm 1.32$ \\
\hline IPA-95 & $143.00 \pm 3.96$ & $135.00 \pm 2.17$ & $229.67 \pm 18.94$ & $278.33 \pm 11.15$ & $195.00 \pm 5.22$ & $98.00 \pm 1.80$ & $35.33 \pm 0.33$ & $4.33 \pm 0.88$ \\
\hline Latefia & $128.00 \pm 9.90$ & $138.25 \pm 10.17$ & $218.75 \pm 13.20$ & \pm 175.754 .44 & $161.00 \pm 11.88$ & $72.00 \pm 6.91$ & $15.25 \pm 1.25$ & $3.00 \pm 0.40$ \\
\hline Rasheed & $139.00 \pm 8.97$ & $139.50 \pm 8.74$ & $165.25 \pm 4.58$ & $296.00 \pm 17.53$ & $218.25 \pm 11.19$ & $90.50 \pm 2.50$ & $28.00 \pm 1.29$ & $3.50 \pm 0.64$ \\
\hline Tammuz & $112.00 \pm 4.94$ & $145.25 \pm 8.37$ & $223.25 \pm 5.70$ & $174.75 \pm 7.96$ & $151.25 \pm 10.16$ & $61.50 \pm 4.03$ & $21.50 \pm 1.19$ & $7.25 \pm 0.85$ \\
\hline
\end{tabular}




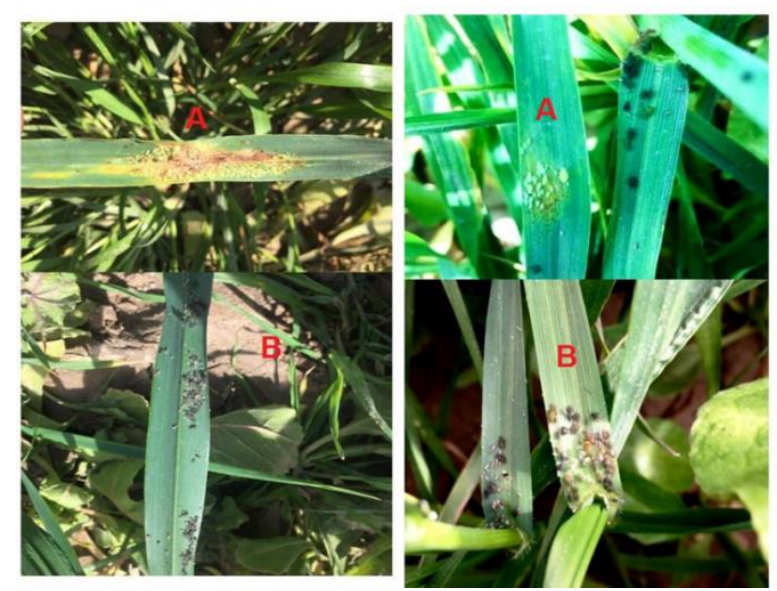

Fig. (5) Damage levels and Greenbug (A) and Bird-Cherry Oat Aphid (B) on the infested wheat crop in the field.

\section{Biochemicals of wheat varieties}

\section{Chlorophyll}

The results of chlorophyll $(a, b$, and total; Table 3) showed significant differences among chlorophyll of local wheat varieties. The varieties Abu-Ghraib and IPA-95 recorded the highest concentration of chlorophyll $a$ at a rate of 2.04 and $2.00 \mathrm{mg} \cdot \mathrm{g}^{-1}$ fresh weight, respectively, which did not differ significantly from the varieties Bhooth-10, Bhooth-158, IPA-99, Fatih, Tammuz, Baraka, and Rasheed. Whereas, the varieties, Bhooth-22 and Babel113 , recorded the lowest levels of chlorophyll $a$, with a rate of 1.66 and $1.89 \mathrm{mg} \cdot \mathrm{g}^{-1}$ fresh weight (f $w$ ), respectively. the results of chlorophyll $b$ indicated the varieties Bhooth-10 and Babel-113 and Latifia recorded the highest average chlorophyll $b$ (3.52, 3.33 and 3.18 $\mathrm{mg} \cdot \mathrm{g}^{-1} \mathrm{fw}$, respectively), while the cultivars Bhooth-22, Abu-Ghraib, and IPA-95 reported the lowest rate of chlorophyll $b$ of $1.67,1.64$ and $1.95 \mathrm{mg} . \mathrm{g}^{-1} \mathrm{fw}$, respectively. the findings of total chlorophyll showed also significant differences among the local wheat varieties; Bhooth-10 and Latifia and Babel-113 recorded the highest rate of total chlorophyll 5.44, 5.25, and $5.07 \mathrm{mg} . \mathrm{g}^{-1} \mathrm{fw}$, respectively, while both varieties Bhooth-22 and IPA-95 had the lowest rate total chlorophyll of 3.34 and $3.68 \mathrm{mg} \mathrm{g}^{-1}$ fw, respectively.

Table (3): Chlorophyll (means \pm SE) of local wheat varieties.

\begin{tabular}{l|ccc}
\hline \multirow{2}{*}{ Varieties } & Chlorophyll $\boldsymbol{a}$ & Chlorophyll $\boldsymbol{b}$ & $\begin{array}{c}\text { Total } \\
\text { Chlorophyll }\end{array}$ \\
\cline { 2 - 4 } & \multicolumn{3}{|c}{$\left(\mathrm{mg} \cdot \mathrm{g}^{-1}\right.$ fresh weight $)$} \\
\hline Abu-Ghraib & $2.04 \pm 0.02$ & $1.95 \pm 0.01$ & $4.00^{\mathrm{f}} \pm 0.02$ \\
Babil-113 & $1.89 \pm 0.04$ & $3.18 \pm 0.03$ & $5.07^{\mathrm{ab}_{ \pm} \pm 0.07}$ \\
Barka & $2.02 \pm 0.03$ & $2.26 \pm 0.03$ & $4.28^{\mathrm{ed}} \pm 0.01$ \\
Bhooth- 10 & $1.92 \pm 0.02$ & $3.52 \pm 0.02$ & $5.44^{\mathrm{a}} \pm 0.01$ \\
Bhooth-158 & $1.97 \pm 0.02$ & $2.26 \pm 0.02$ & $4.29^{\mathrm{ed}_{ \pm}}$ \\
Bhooth-22 & $1.66 \pm 0.06$ & $1.67 \pm 0.05$ & $3.34^{\mathrm{g}} \pm 0.09$ \\
Fatih & $2.02 \pm 0.04$ & $2.33 \pm 0.02$ & $4.36^{\mathrm{ed}} \pm 0.06$ \\
IPA-95 & $2.04 \pm 0.01$ & $1.64 \pm 0.00$ & $3.68^{\mathrm{h}} \pm 0.01$ \\
IPA-99 & $2.00 \pm 0.03$ & $2.48 \pm 0.03$ & $4.48^{\mathrm{c}} \pm 0.06$ \\
Latefia & $1.92 \pm 0.02$ & $3.33 \pm 0.05$ & $5.25^{\mathrm{a}} \pm 0.02$ \\
Rasheed & $1.95 \pm 0.02$ & $2.85 \pm 0.07$ & $4.80^{\mathrm{ab}} \pm 0.06$ \\
Tammuz & $2.01 \pm 0.04$ & $2.13 \pm 0.04$ & $4.14^{\mathrm{ef}} \pm 0.06$ \\
\hline
\end{tabular}




\section{Phenols}

The results of phenols content in the local wheat varieties (Table 4) showed significant differences among the variates. The varieties Rasheed and IPA-99 had the highest level of phenols with a rate of 7 and $6.78 \mathrm{mg} .100 \mathrm{~g}^{-1}$ dry weight, respectively, while Abu-Ghraib was the lowest variety in the phenol contents, with an average of $5.80 \mathrm{mg} .100 \mathrm{~g}^{-1}$ dry weight.

Table (4): The phenol content (Means \pm SE) of local wheat varieties.

\begin{tabular}{l|c}
\hline Varieties & $\begin{array}{c}\text { Total phenols } \\
\text { (mg. 100 g } \mathrm{g}^{-1} \text { dry weight) }\end{array}$ \\
\hline Abu Ghraib & $5.80^{\mathrm{g}} \pm 0.05$ \\
Babil 113 & $5.94^{\mathrm{fg}} \pm 0.07$ \\
Barka & $5.93^{\mathrm{fg}} \pm 0.03$ \\
Bhooth- 10 & $6.53^{\mathrm{bc}} \pm 0.12$ \\
Bhooth- 158 & $6.37^{\mathrm{cd}^{\mathrm{d}}} \pm 0.14$ \\
Bhooth -22 & $6.25^{\mathrm{ed}^{\mathrm{d}} \pm 0.05}$ \\
Fatih & $5.96^{\mathrm{fg}} \pm 0.04$ \\
IPA- 95 & $6.16^{\mathrm{def}_{ \pm 0}} \pm .03$ \\
IPA- 99 & $6.78^{\mathrm{ab}} \pm 0.07$ \\
Latefia & $5.95^{\mathrm{fg}} \pm 0.02$ \\
Rashed & $7.00^{\mathrm{a}} \pm 0.05$ \\
Tammuz & $6.00^{\mathrm{efg}_{ \pm 0}}$ \\
\hline
\end{tabular}

Table (5): percentage of proteins (means \pm SE) in local wheat varieties.

\begin{tabular}{l|c}
\hline Varieties & Proteins\% \\
\hline Abu Ghraib & $24.76^{\mathrm{fg}^{\mathrm{g}} \pm 0.14}$ \\
Babil 113 & $26.80^{\mathrm{d}} \pm 0.10$ \\
Barka & $29.96^{\mathrm{a}} \pm 0.12$ \\
Bhooth- 10 & $25.06^{\mathrm{f}} \pm 0.26$ \\
Bhooth- 158 & $23.53^{\mathrm{hi}} \pm 0.58$ \\
Bhooth -22 & $25.93^{\mathrm{de}} \pm 0.23$ \\
Fatih & $23.30^{\mathrm{i}} \pm 0.25$ \\
IPA- 95 & $27.96^{\mathrm{c}} \pm 0.08$ \\
IPA- 99 & $26.20^{\mathrm{d}} \pm 0.15$ \\
Latefia & $23.60^{\mathrm{hi}} \pm 0.30$ \\
Rashed & $24.16^{\mathrm{gh}^{\mathrm{h}} \pm 0.08}$ \\
Tammuz & $28.80^{\mathrm{b}} \pm 0.11$ \\
\hline
\end{tabular}

Effect of biochemical on the response of local wheat varieties against aphids' infestation

The study of the relationship of biochemical of local wheat varieties with aphids showed a negative correlation between the numbers of $S$. graminum and phenols content and the total chlorophyll content in the leaves, while a very low positive-significant correlation was found between the population densities of Greenbug and the percentage of proteins. Moreover, the correlation between the population of Oat Aphid and the content of biochemical of the varieties was not significant (Table 6).

The results of determining phenol content revealed a significant difference between the susceptible and resistant wheat varieties. The phenol content affected the population density of Greenbug; the higher concentrations of phenol content of the varieties Rasheed and IPA-99 associated with the decrease of the population of Greenbug. Meanwhile, the varieties that infested with a high population of aphids contained a lower proportion of phenols. Leszczynski et al. (1985, 1989) indicated the high inverse relationship between the content of phenols of the wheat plant and the population density of aphids. Phenolic compounds are plant metabolites that enhancing of the plant resistance against the infestation of insect pests (Harborne, 1988; Njom et al., 2017) by affecting the fertility of aphids infested wheat crop during the growing season (Eleftherianos et al, 2006). Leszczyǹski et al. (1985) reported the resistant wheat varieties against aphids associated with high concentrations of phenols, compared to the susceptible varieties, which contained lower concentrations of phenols (Leszczyǹski et al., 1985). The results also revealed the role of chlorophyll in plant resistance to pests. Several studies indicated that resistant wheat varieties 
contain a higher level of chlorophyll $a$ and $b$ compared to susceptible varieties (Heng-Moss et al., 2003), that have lower levels where the insect is attracted to bright green yellow-green leaves (Shibuya et al., 2009).

Table (6): The correlation coefficient of population density of aphids and biochemical of wheat varieties.

\begin{tabular}{|l|c|c|c|}
\hline $\begin{array}{c}\text { The average } \\
\text { number of } \\
\text { aphids }\end{array}$ & Chlorophyll & Phenols & Proteins \\
\hline S. graminum & -0.40 & -0.38 & 0.06 \\
\hline R. padi & 0.10 & -0.26 & 0.05 \\
\hline
\end{tabular}

\section{The productivity of local wheat varieties}

The results of table (7) demonstrated the significant differences in the production of the local wheat varieties in the field. The variety Abu-Ghraib produced the highest yield (47.33 g.1000 grains $^{-1}$ ), followed by the varieties IPA99and Rasheed, of 43, 42.67 g.1000 grains $^{-1}$, respectively. Whereas, the varieties Tammuz and Latifia recorded the least weight of a thousand grains (31 and 31.33 g.1000 grains ${ }^{-1}$, respectively).

As the variety IPA-99, Rasheed, and have the lowest aphid population showed the highest yield significantly. Meanwhile, the variety Abu-Ghraib was infested with high numbers of aphids, and it recorded the highest yield as well; that may be attributed due to the ability of the variety to tolerance the infestation of aphid (Velusamy \& Heinrichs, 1986; Personal unpublished data).

This study agreed with Al-Halfie \& Fleih (2017) who confirmed the high production of the variety Abu-Ghraib. Al-Aseel et al. (2018) mentioned to the high production of the variety IPA-99 compared to Bhooth-22 and other varieties. The high productivity of these varieties may be attributed to genetic factors; in addition to the efficiency of these resistant varieties against aphid infestation, which decreases the production of the infested crop (Kieckhefer \& Gellner, 1992; Riedell, 2003).

Table (7) Productivity (means \pm SE) of local wheat varieties in Basrah Province during the growing season of 2019/2020.

\begin{tabular}{l|c}
\hline Varieties & $\begin{array}{c}\text { Production (g of 1000 } \\
\text { grains) }\end{array}$ \\
\hline Abu-Ghraib & $47.33^{\mathrm{a}} \pm 1.45$ \\
Babil-113 & $35.67^{\mathrm{d}} \pm 0.33$ \\
Barka & $39.40^{\mathrm{c}} \pm 1.15$ \\
Bhooth-10 & $39.00^{\mathrm{c}} \pm 1.52$ \\
Bhooth-158 & $39.00^{\mathrm{c}} \pm 0.33$ \\
Bhooth-22 & $35.33^{\mathrm{d}} \pm 0.57$ \\
Fatih & $33.67^{\mathrm{ed}} \pm 0.57$ \\
IPA-95 & $32.00^{\mathrm{e}} \pm 0.57$ \\
IPA-99 & $43.00^{\mathrm{b}} \pm 0.57$ \\
Latefia & $31.33^{\mathrm{e}} \pm 1.85$ \\
Rasheed & $42.67^{\mathrm{b}} \pm 1.20$ \\
Tammuz & $31.00^{\mathrm{e}} \pm 0.88$ \\
\hline
\end{tabular}

\section{Conclusion}

Due to the results of the current study, the population density of Greenbug, S. graminum, and Bird-Cherry Oat Aphid R. padi were varied among the local wheat varieties. The first infestation of Bird-Cherry Oat Aphid appeared on 1/9/2020, while Greenbug appeared on $1 / 17 / 2020$. Depending on the aphid populations and the analysis of biochemical of the varieties, IPA-99 and Bhooth-10 were classified as resistant varieties against Greenbug while, IPA-99, Bhooth-22, and Bhooth-158 were recorded as resistant varieties against Bird-Cherry Oat Aphid. 


\section{Al-Hussine \& Alyousuf / Basrah J. Agric. Sci., 34(1): 124-138, 2021}

\section{Acknowledgements}

The authors thank the staff of General Organization for Seed Certification, the Technological Centre for Seed Development and the Seed Research Center in Province of Baghdad, Iraq for providing us local wheat varieties.

\section{Conflicts of Interest:}

The authors declare no conflict of interest.

ORCID A. Alyousuf: https://orcid.org/00000002-7352-0168

\section{References}

Al-Aseel, A. S. M., Mahdab, D. S, \& Al-Kathee, .M. H. (2018). Response of bread Wheat (Triticum aestivum L.) cultivars for sowing Dates. Tikrit Journal of Agricultural Sciences, 18, 41-53. https://www.iasj.net/iasj/download/752bd18524649 311

Ali, H. B. (2012). Pictorial key to apterous aphids species (Homoptera: Aphididae, Aphidinae) infested grasses (Gramineae) from several provinces of Iraq. Al-Mustansiriyah Journal of Science, 23, 57-74. https://www.iasj.net/iasj?func $=$ article $\&$ aId $=72442$

Al-Mousawi, A. H., Richardson, P. E., \& Burton, R. L. (1983). Ultrastructural studies of greenbug (Hemiptera: Aphididae) feeding damage to susceptible and resistant wheat cultivars. Annals of the Entomological Society of America, 76, 964-971. https://doi.org/10.1093/aesa/76.6.964

Aslam, M., Razaq, M., Ahma, F., Faheem, M., \& Akhter, W. (2004). Population of aphid (Schizaphis graminum R.) on different varieties/lines of wheat (Triticum aestivum L.). International Journal of Agriculture and Biology ‘6, 974-977

Bakry, M. M., \& Shakal, S. Y. (2020). Population size and spatial distribution pattern of Schizaphis graminum (Hemiptera: Aphididae) on some wheat cultivars and lines. Acta Entomology and Zoology, 1, $1-9$.

Cresser, M. S., \& Parsons, J.W. (1979). Sulphuricperchloric acid of plant material for the determination of nitrogen, phosphorus, potassium, calcium and magnesium. Analytica Chimica Acta, 109 ,

431-436.
https://www.sciencedirect.com/science/article/pii/S 0003267001842732

Central Statistical Organization (CSO), Iraq (2020) Wheat and Parley Production. http://www.cosit.gov.iq/ar/agri-stat/veg-prod

Dreyer, D. L., \& Campbell, B. C. (1984). Association of the methylation of intercellular pectin with plant resistance to aphids and with induction of aphid biotypes. Experientia, 40, 224-226. https://link.springer.com/article/10.1007/BF019636 12

Eleftherianos, I., Vamvatsikos, P., Ward, D., \& Gravanis, F. (2006). Changes in the levels of plant total phenols and free amino acids induced by two cereal aphids and effects on aphid fecundity. Journal of Applied Entomology, 130, 15-19. https://doi.org/10.1111/j.1439-0418.2005.01017.

Gillott, C. (2005). Entomology. Springer Science \& Business Media. 832pp. https://doi.org/10.1007/14020-3183-1

Goodwin, T. W. (1976). Chemistry and Biochemistry of Plant Pigments. Academic Press.495pp. http://agris.fao.org/agrissearch/search.do?recordID=US201300526331

Gu, H., Edwards, O. R., Hardy, A. T., \& Fitt, G. P. (2008). Host plant resistance in grain crops and prospects for invertebrate pest management in Australia: an overview. Australian Journal of Experimental Agriculture, 48, 1543-1548. https://doi.org/10.1071/ea08027

Halfie, S. K. J. (2015). Effect of different levels of Phosphate fertilizer on growth and yield of three cultivars of Wheat (Triticum aestivum L.). M. Sc. Thesis. College of Agriculture, University of Basrah. (English Abstract), 140pp.

Harborne, J. B. (1993). Introduction to Ecological Biochemistry. Gulf Professional Publishing. 318pp

Heng-Moss, T. M., Ni, X., Macedo, T., Markwell, J. P., Baxendale, F. P., Quisenberry, S. S., \& Tolmay, V. (2003). Comparison of chlorophyll and carotenoid concentrations among Russian wheat aphid (Homoptera: Aphididae)-infested wheat isolines. Journal of Economic Entomology, 96, 475-481. https://doi.org/10.1093/jee/96.2.475

Hussein. H. M, \& Al-Nuaimi, K. T. (2013). Laboratory study on the susceptibility of locally bread wheat cultivars to infestation by greenbug. Iraqi Journal of 


\section{Al-Hussine \& Alyousuf / Basrah J. Agric. Sci., 34(1): 124-138, 2021}

Sciences, $\quad 54, \quad 856-861$. https://www.iasj.net/iasj?func $=$ article $\&$ aId $=79401$

Horber, E. (1980). Types and classification of resistance. In Maxwell, F. G., \& Jennings, P. R., (Eds.). Breeding plants resistant to insects. 15-21. https://pascal-

francis.inist.fr/vibad/index.php?action=getRecordD etail\&idt=PASCALZOOLINEINRA82X0380880

Al-Halfie. I. H, \& Fleih. M. I. (2017). Response of two bread wheat varieties yield to mineral, bio-and organic fertilizers. Iraqi Journal of Agricultural Sciences, 48, 1661-1671. http://archivejcoagri.uobaghdad.edu.iq/wp-

content/uploads/sites/8/uploads/Latest\%20Issue/20 17/2017-6-B/8.pdf

Kieckhefer, R. W., \& Gellner, J. L. (1992). Yield losses in winter wheat caused by low-density cereal aphid populations. Agronomy Journal, 84, 180-183. https://doi.org/10.2134/agronj1992.0002196200840 $0020011 x$

Kogan, M., \& Ortman, E. F. (1978). Antixenosis-a new term proposed to define Painter's "nonpreference" modality of resistance. Bulletin of the ESA, 24, 175176. https://doi.org/10.1093/besa/24.2.175

Leszczyński, B., Warchoł, J., \& Niraz, S. (1985). The influence of phenolic compounds on the preference of winter wheat cultivars by cereal aphids. International Journal of Tropical Insect Science, 6, 157-158.

https://link.springer.com/article/10.1017/S1742758 400006548

Leszczynski, B., Wright, L. C., \& Bakowski, T. (1989). Effect of secondary plant substances on winter wheat resistance to grain aphid. Entomologia Experimentalis et Applicata, 52, 135-139. https://onlinelibrary.wiley.com/doi/abs/10.1111/j.15 70-7458.1989.tb01259.x

Ma, R., Reese, J. C., Black I. V., W. C., \& Bramel-Cox, P. (1990). Detection of pectinesterase and polygalacturonase from salivary secretions of living greenbugs, Schizaphis graminum (Homoptera: Aphididae). Journal of Insect Physiology, 36, 507512. https://doi.org/10.1016/0022-1910(90)90102-L

Mitchell, C., Brennan, R. M., Graham, J., \& Karley, A. J. (2016). Plant defense against herbivorous pests: exploiting sistance and tolerance traits for sustainable crop protection. Frontiers in Plant
Science, 7 ,

1132. https://doi.org/10.3389/fpls.2016.01132

Njom, H. A., Mebalo, J., Terefe, T. G., Ndip, R. N., \& Bradley, G. (2017). Phenolics and their potential as biochemical markers for wheat rust and Russian wheat aphid resistance in South Africa. African Journal of Soil Science, 5, 426-434. https://internationalscholarsjournals.org/journal/ajss /articles/phenolics-and-their-potential-as

Page, A. L., Miller, R. H., \& Keeney, D. R. (1982). Methods of Soil Analysis Part 2, Chemical and biological properties 2nd Ed. Agronomy Monograph No. p, American. http://www.sidalc.net/cgi-

bin/wxis.exe/?IsisScript=CENIDA.xis\&method=po st $\&$ formato $=2 \&$ cantidad $=1 \&$ expresion $=m f n=02388$ 5

Papp, M., \& Mesterházy, Á. (1993). Resistance to bird cherry-oat aphid (Rhopalosiphum padi L.) in winter wheat varieties. Euphytica, 67, 49-57. https://link.springer.com/article/10.1007/BF000227 24

Riah, W., Laval, K., Laroche-Ajzenberg, E., Mougin, C., Latour, X., \& Trinsoutrot-Gattin, I. (2014). Effects of pesticides on soil enzymes: A review. Environmental Chemistry Letters, 12, 257-273. https://link.springer.com/content/pdf/10.1007/s1031 1-014-0458-2.pdf

Riedell, W. E., Kieckhefer, R. W., Langham, M. A., \& Hesler, L. S. (2003). Root and shoot responses to bird cherry-oat aphids and barley yellow dwarf virus in spring wheat. Crop Science, 43(4), 1380-1386. https://doi.org/10.2135/cropsci2003.1380

Shibuya, T., Hirai, N., Sakamoto, Y., \& Komuro, J. (2009). Effects of morphological characteristics of Cucumis sativus seedlings grown at different vapor pressure deficits on initial colonization of Bemisia tabaci (Hemiptera: Aleyrodidae). Journal of Economic Entomology, 102, 2265-2267. https://doi.org/10.1603/029.102.0631

Shblawy, L. M., \& Al-Jorany, R. S. (2018). Sunn pest species and its hibernation sites in Diyala governorate/Iraq. The Iraqi Journal of Agricultural Science, $\quad 49, \quad 1118$. http://jcoagri.uobaghdad.edu.iq/index.php/intro/arti cle/view/150

Velusamy, R., \& Heinrichs, E. A. (1986). Tolerance in crop plants to insect pests. International Journal of 


\title{
Al-Hussine \& Alyousuf / Basrah J. Agric. Sci., 34(1): 124-138, 2021
}

Tropical Insect Science, 7, 689-696. https://link.springer.com/article/10.1017/S1742758 400011747

Waterhouse, A. L. (2002). Determination of total phenolics. Current Protocols in Food Analytical Chemistry, 6 , I1-I8. https://doi.org/10.1002/0471142913.fai0101s06

Yahya, M., Saeed, N. A., Nadeem, S., Hamed, M., \& Shokat, S. (2017). Role of wheat varieties and insecticide applications against aphids for better wheat crop harvest. Pakistan Journal Zool, 49, 2217 -
2225 .

https://doi.org/10.17582/JOURNAL.PJZ/2017.49.6. 2217.2225

Zeb, Q., Badshah, H., Ali, H., Shah, R. A., \& Rehman, M. (2011). Population of aphids on different varieties/lines of wheat and their effect on yield and thousands grain weight. Sarhad Journal Agricultural, $\quad 27, \quad 443-450$. http://www.aup.edu.pk/sj_pdf/population\%20on\%2 0aphid.PDF

\section{Schizaphis gramminum تقييم استجابة بعض اصناف الحنطة المحلية للاصابة بحشرة مَّن الحنطة الاخضر ومن الثوفان (Hemiptera: Aphididae) Rhopalosihum padi}

\author{
حيلر ضرب الحسيني1 * وعقيل عدنان اليوسف2 \\ 1 قسم وقاية المزرو عات، مديرية زر اعة البصرة، وزارة الزر اعة \\ 2قفم وقاية النبات، كلية الزر اعة جامعة البصرة، البصرة، العراق
}

المسـتخلص: اجريت دراسـة حقلية ومختبرية لتقييم حسـسية 12 صـنف من اصـناف الحنطة المحلية (اباء 95 واباء 99 و ابو غرب وبابل 113 وبحوث 10 وبحوث 22 وبحوث 158 وبركة وتموز وفتح ولطيفية) ضد الاصـابة بحشرة مَّن الحنطة الاخضر Shizaphis graminum


الحنطة المحلية المزروعة بتاريخداءة 2020/1/9 ، وبلغت ذروتها بتاريخ 2020/1/30، في حين تم تسجيل الاصـابة بنوع مَّن الحنطة الاخضربتاريخ 2020/1/17، والتي بلغت ذروتها بتاريخ 13/2020/2، فقد سجلت النتائج اعلى معدل للكثافة العددية لحشرة مَّن الحنطة الاخضر على الاصناف بحوث 158 وابو غريب وبحوث 22 وبابل 113و البالغة 11.59 و و17.84 و 16.41 و 16.63

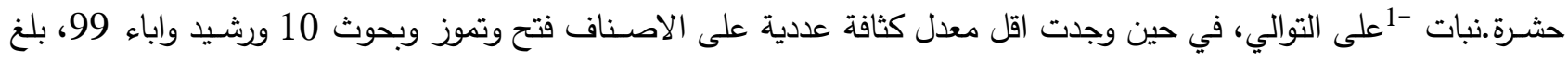

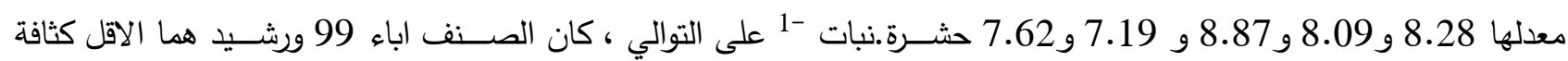



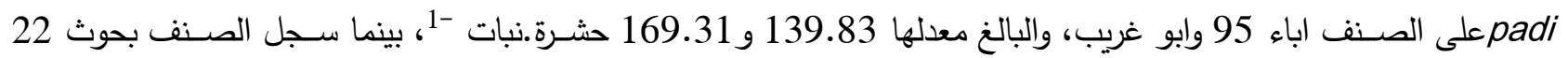

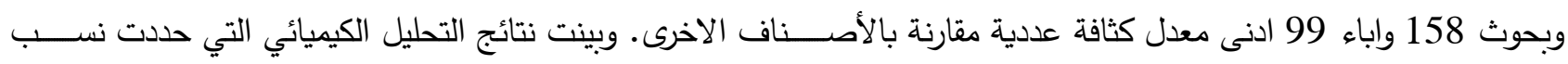


في خفض كثافة حشرة المَّن وذلك من خلال فعلها الطارد والسام ضد الحشرة، اذ سجلت علاقة عكسية مع الكثافة العددية للحشرة على الاصـــناف الحنطة حقلياً، ولوحظ ان الاصــــناف التي احتوت على تراكيز عالية من الفينولات ســـــلت اقل كثافة عددية

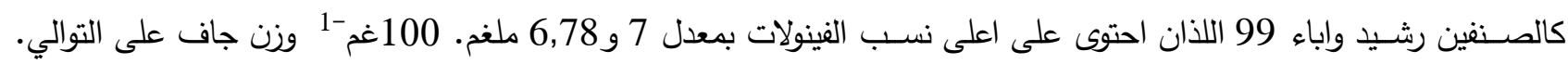
كما سـلت أصناف أبو غريب ، واباء 99، والرشيد أعلى معدلات إنتاجية (وزن الألف حبة) بمتوسط

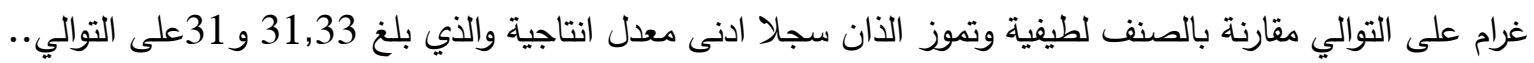

